\title{
Mercaderes y ansias nobiliarias: integración y ascenso social de la familia Malo de Molina*
}

\section{Merchants and noble anxieties: integration and social mobility of the Malo de Molina family}

DAVID MOGROVEJO VIDAL

Pontificia Universidad Católica del Perú

d.mogrovejo@pucp.edu.pe

\section{RESUMEN}

El presente artículo tiene por objetivo analizar las dimensiones social y cultural del ascenso de los mercaderes residentes en el virreinato del Perú en el entramado social, a inicios del siglo XVII, a partir del proceso de integración a la elite de Melchor Malo de Molina. Este fue un mercader español que llegó al Perú a finales del siglo XVI y que, en solo algunas décadas, llegó a formar parte de los círculos más prestigiosos de dicha sociedad. Se propone que la vinculación y control sobre el patrimonio de familias de la elite y la construcción de una imagen pública de nobleza fueron pilares esenciales de su éxito.

Palabras clave: Elite, redes, mercaderes, nobleza, ascenso social.

* Este artículo está basado en la tesis para optar por el grado de licenciatura en Historia «Élite, comercio y movilidad social: el ascenso social de la familia Malo de Molina 1589-1640» bajo la asesoría de la doctora Margarita Suárez. Agradezco asimismo a los evaluadores anónimos por sus comentarios. 


\section{ABSTRACT}

This paper discusses the social and cultural dimensions of the merchant's upward social mobility in the Viceroyalty of Peru during the 17th century from the case study of Melchor Malo de Molina's elite integration. This Spanish merchant arrived in Peru in the late 16th century and, in a few decades, became a prominent member of Peruvian society's most exclusive circuits. I propose that his bonding and control over other prestigious families' patrimony and the construction of a public image of nobility were key in his success.

Keywords: Elites, merchants, networks, nobility, social mobility.

Dara finales del siglo XVI, el virreinato del Perú había dejado de ser
un espacio dominado por la violencia y las guerras que caracterizaron los primeros años de la Conquista y las subsecuentes luchas entre facciones de conquistadores y encomenderos. El auge minero, producto de los descubrimientos de yacimientos en Huancavelica y Potosí, y el establecimiento de un sistema de flotas estable como medio principal de conexión entre América y Espańa dinamizaron la economía del virreinato peruano. ${ }^{1}$ El boom de la plata americana produjo un efecto de arrastre en los demás sectores productivos del territorio, que a su vez configuraron un complejo sistemas de circuitos comerciales que conectaban áreas geográficamente distantes. ${ }^{2}$ Así, la gran demanda de productos en ciudades y centros mineros convirtió al comercio en una actividad altamente lucrativa, en la cual la ciudad de Lima se convertiría en el eje principal. La magnitud de este crecimiento fue tal que sorprendió a varios cronistas de la época, como el padre Bernabé Cobo, quien, en su Historia de la Fundación de Lima, enfatizó el carácter comercial de la ciudad dado que «solo las tiendas de los mercaderes pasan de ciento y cincuenta» ${ }^{3}$ y que en sus calles era "muy grande el bullicio y tráfico del comercio, especialmente al tiempo en que se despachan las armadas». ${ }^{4}$

\footnotetext{
1 Andrien 2011: 30 .

2 Assadourian 1982: 114-115.

3 Cobo 1882: 78.

${ }^{4}$ Ib.: 76.
} 
Pese a su importancia para la economía, la posición social de los mercaderes, principales engranajes de esta actividad, fue un tanto ambigua, especialmente durante las primeras décadas del dominio hispano. La presencia de mercaderes en Hispanoamérica se puede rastrear desde los mismos inicios de la Conquista. De la mano de los cientos de conquistadores, arribaron al territorio muchos mercaderes que financiaban las expediciones y que mantenían el suministro de pertrechos necesarios para la viabilidad de estas. Una vez acabadas las guerras, su labor adquirió aun más importancia, dado que ellos mantenían el suministro de objetos cotidianos y bienes de lujo que permitían el desenvolvimiento de la vida social en América. 5 Sin embargo, durante los primeros años, los mercaderes no gozaron de una posición privilegiada en estas sociedades y estuvieron sujetos a los mismos prejuicios existentes sobre su profesión en Europa. Esta actitud los alejó de las inversiones destinadas al establecimiento en el territorio. Por el contrario, muchos de ellos invertían únicamente en vivienda y tiendas necesarias para el desarrollo de sus actividades, mientras ahorraban lo suficiente para regresar a Sevilla donde podrían buscar mejores oportunidades a fin de este ascenso. ${ }^{6}$

Para inicios del siglo XVII, las nuevas condiciones económicas y los grandes ingresos producidos por esta profesión generaron un sector acaudalado dentro de la sociedad limeńa, la cual inició un camino de integración social. Además, su cercanía con la administración virreinal los colocó en una posición privilegiada para poder negociar beneficios sociales a cambio de su ayuda en contextos de necesidad económica. ${ }^{7} \mathrm{No}$ obstante, su ingreso a la elite del virreinato no fue inmediata y presentó algunas resistencias. Como toda sociedad de Antiguo Régimen, en la temprana Lima colonial, el estatus no estaba únicamente vinculado al patrimonio, sino también a una serie de requisitos adicionales que constituían el ideal de nobleza de la época. Su condición de mercaderes les supuso obstáculos a su integración dentro de los estratos más altos de la sociedad estamental colonial y fueron, en muchos casos, injuriados

\footnotetext{
${ }^{5}$ Lockhart 1982: 123-124.

${ }^{6}$ Ib.: 104-108.

${ }^{7}$ Rodríguez Vicente 1960: 149.
} 
por su profesión. ${ }^{8}$ No obstante, para mediados del siglo XVII, muchos mercaderes ya eran parte integral de los sectores más prestigiosos en lugares como Buenos Aires, Lima, Quito y Ciudad de México. ${ }^{9}$ El camino para lograr este reconocimiento necesitó de mucho más que solo la acumulación de dinero, sino también su capacidad para adaptarse a los requerimientos que la sociedad les exigía.

Es en este contexto que la trayectoria de ascenso social del mercader Melchor Malo de Molina resulta llamativa para entender dicho proceso. Este mercader nació en la ciudad española de Cuenca en 1573 y fue hijo legítimo de Pedro Malo de Molina y María de Alarcón. Es poca la información con la que se cuenta sobre sus primeros años en el Perú. Según una carta suya, fue parte del séquito del virrey marqués de Cañete que llegó a América en $1589 .{ }^{10}$ Durante las últimas décadas del siglo XVI, se asentó en la ciudad de Huamanga donde se desempeñó como mercader. Desde esta ciudad, adquiría productos llegados a Lima través de la armada y los comercializaba en el mercado interior peruano, especialmente en los circuitos que integraban las ciudades de Cusco y Huamanga. Esta primera experiencia en las rutas comerciales del interior le otorgó un gran conocimiento sobre los negocios con productos provenientes de Europa y otras partes. ${ }^{11}$

Para 1610, Malo de Molina dio el salto hacia la capital donde, según las escrituras notariales de la época, aparece entablando relaciones comerciales con varios personajes bajo el rótulo de mercader residente en Lima. A mediados de esta misma década, empezó a participar directamente en el comercio ultramarino a través del despacho de agentes a la feria de Portobelo. Desde 1620, se puede observar en su actividad una continuidad casi anual en el envío de plata a través de la armada y el empleo de una gran cantidad de agentes para la compra de mercaderías en el ya mencionado mercado en Portobelo, y ocasionalmente a México y Sevilla. ${ }^{12}$ A partir

\footnotetext{
8 Suárez 2001: 188-190.

9 Ver Suárez 2001; Ponce Leiva 1998; Peña 1983 y Hoberman 1991.

${ }^{10}$ Lohmann 1983, II: 190.

${ }^{11}$ Mogrovejo Vidal 2019: 42-43.

12 Ib.: 45-49.
} 
de los réditos obtenidos en el comercio, Malo de Molina fue capaz de incrementar enormemente su patrimonio invirtiendo en otros tipos de negocios. Además, convirtió a su familia en una de las más prestigiosas y reconocidas del virreinato, de manera que dos generaciones después, su nieto Melchor Malo de Molina y Sotomayor logró acceder a un título nobiliario como marqués de Monterrico. ${ }^{13}$

Desde hace algunos años, la historiografía sobre los mercaderes ha hecho énfasis en la importancia de las redes en los procesos de integración de foráneos, migrantes y extranjeros en las sociedades hispanoamericanas. Este grupo de investigaciones ha señalado la enorme cantidad de vínculos entre dichos individuos y los diferentes sectores que conformaban su medio social. Según este enfoque, fueron las redes, y no las filiaciones institucionales, la base para la formación de grupos de poder que negociaron y actuaron en favor de intereses en común. ${ }^{14}$ A pesar de estos avances, queda todavía un gran camino por entender las implicancias que tuvieron estos vínculos en cada una de las partes involucradas en dichas alianzas.

En ese sentido, el objetivo de este artículo es analizar las dimensiones social y simbólica en el proceso de integración de Melchor Malo a la elite peruana. Concretamente, qué tipo de relaciones se establecieron entre este mercader y su medio social, y sobre la base de qué nociones logró su reconocimiento son algunas de las preguntas que guiaron esta esta investigación. Se propone que, en un contexto de condiciones sociales, económicas y políticas favorables para el ascenso social de los mercaderes, el control sobre el patrimonio de algunas familias de la elite peruana a través de vínculos matrimoniales y la posterior elaboración de una imagen pública distanciada del comercio y asociada a la del modelo de nobleza existente fueron pilares centrales de su reconocimiento y el de sus descendientes como miembros legítimos del sector más prestigioso de dicha sociedad.

${ }^{13}$ Para un análisis de los negocios transatlánticos de Melchor Malo de Molina, ver Mogrovejo Vidal 2019.

${ }^{14}$ Ver Ponce Leiva 1998; Suárez 2001; Sullón 2016; Valle Pavón e Ibarra 2017. 
ELITES, MERCADERES Y JERARQUÍAS SOCIALES A FINALES DEL SIGLO XVI

Desde la fundación del virreinato del Perú, el grupo más prestigioso y privilegiado de la sociedad colonial peruana estuvo compuesto por los beneméritos, es decir, los descendientes de los conquistadores. Estos habían recibido encomiendas o el disfrute del tributo de un número determinado de indígenas como recompensa a su labor en la conquista. Con estas rentas, los encomenderos amasaron grandes fortunas que les permitieron costear una vida llena de pompa y lujos al mismo estilo que la nobleza europea. ${ }^{15}$ De esta forma, la elite peruana durante el siglo XVI se constituyó a partir de la formación de grandes linajes de beneméritos, como Jerónimo de Aliaga, Nicolás de Ribera o Francisco de Ampuero, respetados por todos los sectores de la sociedad. ${ }^{16}$

Pese a sus pretensiones, los beneméritos no lograron acceder a títulos nobiliarios que consolidasen su posición como nobleza de la tierra. Más aun, la misma institución de la encomienda se regía bajo ciertas restricciones que impedían el establecimiento de un sistema puramente señorial como el de la aristocracia europea. ${ }^{17}$ La principal de estas restricciones fue su carácter temporal, limitado a dos o tres vidas y no perpetuo, como aspiraban los beneméritos. Muchas familias lograron evadir este requerimiento por algunas generaciones; no obstante, dicha condición siempre generó incertidumbre sobre el futuro económico familiar. ${ }^{18}$

Debido a estas condiciones, no existió un estamento propiamente nobiliario hasta finales del siglo XVII, cuando la Corona inició una política de ventas y beneficios de títulos de Castilla a los criollos en América. ${ }^{19}$ Sin embargo, la ausencia de títulos no impidió que muchos personajes emularan el estilo de vida de la nobleza e incluso exigieran algunos tratamientos reservados para ese sector. Para finales del siglo XVI, la elite local del virreinato encontró otros atributos a partir de los cuales pudo construir su imagen de nobleza y estatus que los diferenció tanto de las

\footnotetext{
${ }^{15}$ Evans 1972: 45.

${ }^{16}$ Ib.: $13-14$.

${ }_{17}$ Puente Brunke 1991: 300.

${ }^{18}$ Ib.: 78.

19 Jiménez Jiménez 2017: 60-62.
} 
castas como del abundante número de migrantes españoles que, para ese entonces, residían en todas las ciudades del virreinato. El disfrute de una encomienda, la posesión de un hábito militar o la pertenencia a la Compañía de Gentilhombres, Lanzas y Arcabuces han sido señalados por la historiografía como algunos de los principales caminos para exteriorizar esta condición sin la necesidad de contar con un título formal. ${ }^{20}$ Esta actitud se volvió tan común, que en 1635 el depositario general del Cabildo de Lima, Jerónimo López de Saavedra, señaló a modo de queja que en la ciudad era suficiente hacerse llamar hidalgo para lograr dicho tratamiento. ${ }^{21}$

Si bien las palabras de López de Saavedra podrían estar exagerando la facilidad con la que se lograba la hidalguía, nos da pistas acerca del proceso detrás de la obtención de ese reconocimiento. Ante la ausencia de factores más tradicionales como los títulos, las elites en el virreinato del Perú cimentaron su distinción sobre otras cualidades más fáciles de obtener, pero igual de efectivas para proyectar el estatus al cual aspiraban. Fueron cualidades a partir de las que era posible construir una imagen pública de prestigio y estatus que otorgase a su portador los honores y dignidades del sector más prestigioso. En ese sentido, el reconocimiento público fue fundamental para iniciar cualquier camino de ascenso.

Fue esta característica de las jerarquías sociales existentes tanto en el Perú y en otras áreas de Hispanoamérica lo que configuró un espacio para el ascenso social de personajes advenedizos que supiesen hacerse de estos atributos. Para mediados del siglo XVII, es posible observar una escalada generalizada de muchas familias vinculadas al comercio en los principales centros de la monarquía española. En Sevilla, familias de comerciantes como los Corzo y los Mañara construyeron verdaderos imperios comerciales en las rutas de los océanos Atlántico y Pacífico. Una vez acumulado el dinero, empezaron lo que Enriqueta Vila Vilar denominó las inversiones con interés social o la inclinación de las familias de comerciantes por revestir su patrimonio para asemejarlo al de la tradicional nobleza. ${ }^{22}$ Inversiones como la compra de tierras, los juros,

\footnotetext{
${ }^{20}$ Bronner 1977: 637-639.

${ }^{21}$ Ib.: 637.

${ }^{22}$ Vila Vilar 1991: 138-139.
} 
los hábitos militares y la creación de mayorazgos fueron algunas de las estrategias que emplearon los adinerados mercaderes de esta ciudad para lograr este objetivo. ${ }^{23}$

En América, se dio un proceso similar de ascenso en el que los grandes comerciantes, frente a la ausencia del segmento nobiliario establecido y la debilidad económica de los beneméritos, lograron convertirse en uno de los sectores con mayor prestigio e influencia política del territorio. En el caso de Nueva Espańa, el estigma contra la profesión del comercio no fue un impedimento para que algunos personajes consigan establecerse como miembros de la elite. Para mediados del siglo XVII, un gran porcentaje de los grandes comerciantes de la ciudad de México y sus hijos habían optado por adquirir un cargo público o convertirse en propietarios de grandes extensiones de tierras. ${ }^{24}$ De igual manera, la composición social del cabildo de la ciudad estaba en pleno proceso de transformación. Las grandes familias habían sido desplazadas de los puestos de regidores por personajes cuyas fortunas procedían del comercio y el préstamo de dinero. ${ }^{25}$

Un ascenso similar sucedió en la capital del virreinato del Perú, en el que un conjunto de mercaderes y banqueros asociados al Tribunal del Consulado lograron consolidarse como uno de los grupos de poder con mayor estatus e influencia. Los llamados "peruleros», debido a su participación en el comercio transatlántico que unía a Sevilla con la costa del Pacífico sur, utilizaron las enormes ganancias de este negocio para expandir su influencia sobre otros rubros. Por un lado, controlaron la producción de los metales de los yacimientos de Potosí y Huancavelica a través del otorgamiento de préstamos a los mineros, lo que les otorgó acceso directo a las barras; ${ }^{26}$ y, por otro, solventaron los gastos de la administración real que no siempre contaba con la liquidez necesaria para mantenerse. Banqueros como Juan de la Cueva o Bernardo de Villegas son ejemplos de esta dinámica. Ambos prestaron a la Real Hacienda más

${ }^{23}$ Ib.: 135-140.

${ }^{24}$ Hoberman 1991: 232-234.

${ }^{25}$ Peña 1983: 153-157.

${ }^{26}$ Suárez 2001: 178-185. 
de dos millones de pesos, el $76 \%$ de los préstamos hechos por las cajas reales del reino entre 1615 y $1634 .^{27}$

De igual forma que sus pares en Sevilla y algunas ciudades de la Nueva España, los peruleros emprendieron un camino hacia la obtención de honores para lograr consolidar una posición dentro de la élite del virreinato. Durante las primeras décadas del siglo XVII, se observa por parte de este grupo un apetito por conseguir los mismos beneficios que los beneméritos habían accedido décadas atrás. El cabildo fue nuevamente uno de los primeros espacios en ser acaparados por estos personajes. Mercaderes como Juan Arias de Valencia, Pedro Sánchez Garcés, Francisco de la Presa y muchos otros más lograron obtener puestos como regidores perpetuos. ${ }^{28}$ Para la década de 1630, menos del $20 \%$ de los regidores perpetuos poseía una encomienda, prueba de que no formaban parte de la tradicional clase benemérita que había monopolizado esta institución desde su fundación. ${ }^{29}$ Adicionalmente, consiguieron hacerse de otros honores disponibles como las familiaturas del Santo Oficio y los muy prestigiosos hábitos de órdenes como la de Santiago y Alcántara, que fueron ostentados por reconocidos priores y cónsules del Tribunal del Consulado como Antonio de Mioño, Juan de Urdanegui y Juan de Murga. ${ }^{30}$

Es en este escenario en el que se desenvolvió Malo de Molina. De manera paralela a sus negocios, este mercader emprendió su camino en la obtención de estos elementos con un resultado notoriamente exitoso. La necesidad por pertenecer a un linaje y de reconocimiento público de su nueva condición, lo llevaron a entablar, por un lado, vínculos matrimoniales con miembros de la elite que ya contaban con una estirpe establecida y, por otro, a construir una imagen pública acorde al estatus que aspiraba. De esta manera, Malo de Molina fue capaz de trasladar todo ese bagaje simbólico a su apellido y convertirlo en uno al cual diversos sectores de la sociedad limeńa le concedían prerrogativas similares al estamento nobiliario.

27 Ib.: 271.

28 Ib.: 191.

${ }^{29}$ Mogrovejo Vidal 2019: 35.

${ }^{30}$ Suárez 2001: 192-193. 


\section{INTEGRACIÓN A LA ELITE: LAS ALIANZAS MATRIMONIALES}

Las uniones matrimoniales establecidas por Malo de Molina para sus familiares resultan interesantes por los beneficios que logró extraer de ellas. No fue únicamente la unión con familias beneméritas lo que ayudó al clan Malo de Molina en su proceso de ascenso, sino también la relación jerarquizada establecida entre ambas, lo cual nos dice mucho acerca de cómo ciertas familias fueron prácticamente absorbidas dentro de la influencia de un clan comercial. En 1596, Malo de Molina se casó con Mariana Ponce de León, hija del capitán Juan Ponce de León, quien fue alférez mayor de la ciudad de Huamanga y cuya familia poseía una encomienda desde los primeros años de la conquista. ${ }^{31}$ Además, esta familia también descendía de Pedro de Rivera, que fue gobernador y capitán general de la provincia de Huamanga, como se menciona en el informe presentado por uno de los hijos de Malo de Molina para la obtención del hábito de la Orden de Santiago. ${ }^{32}$ Los Ponce de León, eran, en todo sentido, una familia de prestigio y estatus en los círculos sociales de dicha ciudad.

Este tipo de uniones entre las antiguas familias de encomenderos y comerciantes fue común desde finales del siglo XVI. El descenso de las rentas producidas por las encomiendas ocasionó que sus poseedores busquen otras fuentes de ingreso para poder mantener un estilo de vida acorde a su estatus. Los mercaderes, por su parte, vieron en la unión con los beneméritos un acceso fácil a las elites locales y un camino para que sus apellidos puedan impregnarse de todo de todo el prestigio negado debido a su profesión. ${ }^{33}$ La familia Ponce de León parece haber estado dentro de este grupo de encomenderos afectados por el declive de la institución. La encomienda que poseía el hermano de Mariana, Juan Ponce de León, contaba con 150 indios tributarios que le otorgaban una renta anual de 321 pesos 2 reales y 6 granos. ${ }^{34}$ Una suma ínfima que por sí sola era insuficiente para mantener el estilo de vida de una

${ }^{31}$ Lohmann Villena 1983, II: 191.

${ }^{32}$ Archivo Histórico Nacional, Madrid [en adelante AHN]. OM-Expedientillos, N. 2033.

33 Suárez 2001: 150.

${ }^{34}$ Puente Brunke 1991: 391. 
familia de beneméritos. Por ello, un poseedor de lucrativos negocios en Huamanga como Malo de Molina se presentaba como un codiciable candidato para un matrimonio beneficioso.

Es interesante señalar que este primer paso en el camino de ascenso de Malo de Molina se haya dado en una ciudad de mediana importancia dentro del virreinato del Perú tal como era Huamanga y no en otras más grandes y prósperas. Para un personaje como este, con todavía un corto tiempo en el Perú, la integración a una elite regional pudo haber sido mucho más accesible para entablar vínculos matrimoniales que hacerlo con las familias de beneméritos en ciudades como Lima o Arequipa, quienes aspiraban a más en términos de linaje, dote o influencia política. Una familia como los Ponce de León, que no era de las más prestigiosas del reino, pero que poseía una reputación ganada por lo menos dentro de la ciudad de Huamanga, pudo haber visto en Malo de Molina — y su todavía modesta fortuna - un candidato ideal para preservar su bienestar económico y social frente a una reducción de ingresos o la incertidumbre económica por la que pasaban todas las familias de encomenderos a inicios del siglo XVII.

El sostén económico que prestó Malo de Molina a la familia de su esposa es fácilmente apreciable en las escrituras notariales. En 1621, este otorgó un préstamo al hermano de Mariana, Juan Ponce de León, de 4142 pesos de 8 reales. ${ }^{35}$ Dos años después, este mismo hermano reconoció que debía a su cuñado 7000 pesos de 8 reales que «me ha prestado a mí el dicho principal con consentimiento de mi madre en diferentes veces y partidas para mis alimentos y pagar costos de los pleitos que contra mí se han seguido en la Real Sala del Crimen y Condenaciones». ${ }^{36}$ Es seguro suponer entonces que, por varios años, Malo de Molina había costeado las necesidades de la familia Ponce de León a partir de pequeńas partidas de dinero que ahora eran consignadas como préstamos en los documentos notariales. El mercader no parece haber tenido prisa en cobrar estas deudas dado que la última escritura

${ }^{35}$ Archivo General de la Nación, Lima [en adelante AGN], Protocolos notariales siglo XVII, N. 1208. f. 121.

${ }^{36}$ AGN, Protocolos notariales siglo XVII, N. 1212, f. 1997-1998. 
mencionada consigna un periodo de siete años para la devolución del dinero, plazo para nada común en las transacciones financieras que el solía realizar con otros personajes. Este crédito privilegiado parece haber sido más bien la formalización legal del nuevo rol que cumplía Malo de Molina dentro de la familia Ponce de León.

Esta condición de sostén de la familia le otorgó a Malo de Molina un dominio sobre el patrimonio y los ingresos de la familia Ponce de León que se percibe a través de las cesiones y poderes que se dan a su favor. El 18 de enero de 1621, Ponce de León le otorgó un poder para que lo represente en cualquier pleito, demanda, ejecución o cobro que corresponda al manejo de su patrimonio. ${ }^{37}$ Posteriormente, en 1623, el mismo otorgante, quien estaba de partida para Chile, le otorgó un poder completo al mercader para cobrar en su nombre por vía judicial o extrajudicial a cualquier persona que le deba dinero, acto que terminó por sellar el rol dirigente que adquiría nuestro personaje dentro de esta familia. ${ }^{38}$

Es a partir de estos años que se puede observar el uso que le dio Malo de Molina al patrimonio de la familia de su esposa como administrador de sus bienes, pero también el uso para beneficio propio. En 1621, Ponce de León y su esposa Mariana de la Torre Izazaga otorgaron un poder a nuestro personaje para cobrar para sí lo que se les debiere por el repartimiento de los indios quiguares en pesos, especies y otros frutos. ${ }^{39}$ En 1625, Malo de Molina menciona que ya desde 1620 tenía un poder por parte de Ponce de León y su esposa para hacer uso de los frutos del repartimiento llamado Espíritu Santo en el corregimiento de Azángaro. En calidad de receptor, cedía dichos frutos a Francisco Gómez Calderón, vecino de Huancavelica, para que pueda cobrar los tributos para sí o cederlos a un tercero por el tiempo de tres ańos. ${ }^{40}$

En 1632, haría nuevamente lo mismo con Esteban Pardo de Castillón, a quién le cedería los tributos del mismo repartimiento por dos años a cambio de 1027 pesos de 8 reales, de los cuales 513 se adelantaron

${ }^{37}$ AGN, Protocolos notariales siglo XVII, N. 1208, f. 119.

${ }^{38}$ AGN, Protocolos notariales siglo XVII, N. 1212, f. 1998v-2000.

${ }^{39}$ AGN, Protocolos notariales siglo XVII, N. 1208, f. 119.

${ }^{40}$ AGN, Protocolos notariales siglo XVII, N. 1216, f. 2187-2188. 
a través del banco de Juan de la Cueva. Junto con el monto total por la cesión, esta escritura también consigna que los tributos entregados por este repartimiento consistían en 8 fanegas de maíz, 48 fanegas de papas, 300 aves (entre pollos y gallinas) y 220 pesos de 8 reales, ${ }^{41}$ cantidades ínfimas si se le compara las ganancias que tenía este personaje por la venta de mercaderías procedentes la feria de Portobelo por esos mismos $a_{n} s^{42}$. Este no fue el único corregimiento que fue posesión de la familia Ponce de León. En 1631, Malo de Molina entregó un poder a Francisco de Almeida, vecino de Huamanga, para cobrar los tributos de las cajas de la comunidad de Vilcas y Angares que le correspondían. ${ }^{43} \mathrm{Al}$ siguiente ańo, volvió a emitir el mismo poder a la misma persona junto con Alonso de Paredes, comisario del Santo Oficio, a quien también le cedió la posesión de una casa huerta. ${ }^{44}$

Dos de estos personajes eran también socios comerciales de Malo de Molina. En 1625, Francisco Almeida aparece como agente de reemplazo del hermano de este mercader llamado Baltazar Malo de Molina para recibir un cargamento de dos fardos con mercaderías enviadas por Melchor de Lima a la villa de Huamanga ${ }^{45}$ Francisco Gómez Calderón era vecino y regidor en la villa de Huancavelica y comerciaba constantemente en los circuitos mineros de esa zona. En 1616, este recibió un préstamo de Malo de Molina por 7270 pesos de 8 reales para la compra de mercaderías. ${ }^{46}$ Dos años después, le compró, junto con otros vecinos de la ciudad de Huancavelica, a Malo de Molina casi 5000 varas de ruan de fardo 4500 pesos de 8 reales. ${ }^{47}$ En 1621, Melchor le otorgó un poder a Gómez Calderón para que pueda cobrar en su nombre todas las deudas y negocios pendientes que tenía en dicha villa. ${ }^{48}$ Por tanto, la cercanía de estos personajes con Malo de Molina da cuenta que este

41 AGN, Protocolos notariales siglo XVII, N. 1228, f. 1101-1102.

42 Mogrovejo Vidal 2019: 48.

43 AGN, Protocolos notariales siglo XVII, N. 1231, f. 82r-83v.

44 AGN, Protocolos notariales siglo XVII, N. 1231, f. 199r-200v.

45 AGN, Protocolos notariales siglo XVII, N. 1216 (1625), f. 2465 r.

46 AGN, Protocolos notariales siglo XVII, N. 1203 (1616), f. 692.

47 AGN, Protocolos notariales siglo XVII, N. 1206 (1618), f. 1503-1507v.

48 AGN, Protocolos notariales siglo XVII, N. 1209 (1621), f. 1913v-1914. 
asimiló el patrimonio de la familia de su esposa al punto que lo utilizó como un elemento más en sus negocios comerciales. Su procedencia del comercio y experiencia en el manejo de recursos le permitió hacer un uso más eficiente del patrimonio de la familia Ponce de León y otorgarle, en el largo plazo, estabilidad económica.

La unión entre el mercader y los beneméritos no solo le permitió al primero acceder a un sector social privilegiado y hacer uso de su patrimonio, sino que también le otorgó acceso a un recurso más inmaterial, pero con mucho potencial para extraer un beneficio: el favor real. En 1623, Ponce de León le otorgó un nuevo poder a Malo de Molina para

que pueda parecer y parezcan ante el Rey nuestro señor y excelencia el señor Visorrey de estos reinos y ante quien derecho deba y pedir y suplicar que en remuneración de los servicios que a Su Majestad han hecho mis padres y antepasados se haga merced de cualesquier encomiendas de indios, cuentas y otras cosas que se pareciere conforme a lo méritos de los dichos servicios. ${ }^{49}$

La cesión de este poder implicaba que Malo de Molina podía apelar al mismo mecanismo utilizado por lo beneméritos para acceder a cualquier merced real, un camino que le daría mayor capacidad de negociación ante las autoridades reales. De esta manera, la unión entre ambas familias le permitió al mercader acceder al mismo favor real que la tradicional élite limeña, así como al manejo de un patrimonio que complementaría el ya obtenido a través del comercio y los negocios. Para 1635, Mariana de la Torre Izazaga, suegra de Melchor Malo, finalmente dio poder para testar a su yerno y le legó la posesión de unas casas y tiendas en la plaza de Huamanga para su segundo nieto Pedro Malo de Molina, ${ }^{50}$ diluyéndose así el patrimonio de los Ponce de León en la familia del yerno.

El mismo patrón de vinculación en donde confluyen linajes prestigiosos, vinculaciones sociales y negocios se puede observar entre las uniones matrimoniales de los hijos Malo de Molina. A partir de estos, Malo de Molina construyó vínculos con círculos sociales a los que el mercader buscaba acceder. En el caso de su hija María Margarita Malo de

${ }^{49}$ AGN, Protocolos notariales siglo XVII, N. 1212, f. 1998v-2000.

${ }^{50}$ AGN, Protocolos notariales siglo XVII, N. 1235, f. 794. 
Molina, ella se unió con Agustín Messía de Córdova, alguacil mayor de corte de la Audiencia de Lima, matrimonio que no duraría mucho tiempo debido a la muerte de este último en 1626. Esta no pasaría soltera mucho tiempo, pues contrajo nupcias nuevamente con Bernardino Hurtado de Mendoza, general de la Armada del Mar de Sur y personaje cercado al virrey Conde de Chinchón, a quién se le otorgó la impresionante dote de 100000 pesos de 8 reales. ${ }^{51}$ Si analizamos con detenimiento ambas uniones, es posible identificar cómo en ambos casos el linaje de los Malo de Molina se beneficiaría social y económicamente con estas.

Por un lado, la unión de su hija como Messía de Córdova le otorgó acceso a un cargo dentro de la administración que lo posicionó dentro de un espacio formal del ejercicio del poder. Messía de Córdova hizo cesión a Malo de Molina de la vara de alguacil mayor de corte de la Audiencia de Lima. Este era un cargo honorífico de dichos tribunales que le otorga, entre diversas otras funciones, la preeminencia de sentarse cerca de los jueces en las salas de crimen, así como participar como parte de esta institución en las fiestas y celebraciones ${ }^{52}$. El traspaso del cargo resultó controversial dado que fue acusado de falsificar dicha cesión y no pudo tomar posesión de este después de un largo pleito que duraría hasta 1633 e involucró un donativo de 11000 pesos de 8 reales. ${ }^{53}$ Esta vara se mantendría como parte de la familia hasta dos generaciones después cuando finalmente fue vendida por Melchor Malo de Molina y Aliaga.

Por otro lado, la unión con la familia Hurtado de Mendoza probaría ser igual de útil para su camino en el ascenso. Bernardino Hurtado de Mendoza, hijo de Lope Hurtado de Mendoza y Clara Larrea Zurbano, fue corregidor del puerto de Arica y para inicios de la década de 1630, llegó a ser general de la Armada del Mar del Sur. ${ }^{54}$ Los vínculos comerciales entre ambas familias resaltan durante el mismo periodo de la unión. En 1622, Melchor Malo dio poder a un familiar de su yerno Bernardino llamado Luis Hurtado de Mendoza, tesorero y juez oficial de la Real Hacienda

\footnotetext{
${ }^{51}$ Lohmann Villena 1983, II: 191.

52 Cornejo 1779: 50.

${ }^{53}$ Lohmann Villena 1983, II: 191.

${ }^{54}$ Sánchez Concha 2019: 677
} 
en la villa de Potosí, para que pueda cobrar y vender en esa ciudad 433 quintales de fierro a Juan Martínez y 1180 pesos de 8 reales de dos dueños de recuas y se lo remita lo procedido a Lima a riesgo del otorgante. ${ }^{55}$ En 1637, una escritura da cuenta de un préstamo otorgado en 1627 por Baltazar Malo de Molina, hermano de Melchor y también su principal agente de negocios, a Bernardino Hurtado de Mendoza como principal y a Juan de Sarria, factor de Malo de Molina en la ciudad de Panamá, por cantidad de 2200 pesos de 8 reales. En 1628, Baltazar declaró que esta deuda en realidad le pertenecía a Melchor, quien finalmente la cedió a su hermano. ${ }^{56}$ Este tipo de triangulaciones comerciales dan cuenta de que, para el momento de la unión matrimonial, la familia Hurtado de Mendoza era parte de la red comercial de los Malo de Molina.

De la misma manera que con la familia Ponce de León, una vez fallecido Bernardino Hurtado de Mendoza, nuestro personaje tomaría el control tanto de sus negocios como de su patrimonio. En 1636, Hurtado de Mendoza concedió un poder para testar a Malo de Molina, a su esposa Margarita y a Antonio de Miońo, miembro del Tribunal del Consulado. ${ }^{57}$ Ese mismo ańo ya se puede identificar a Melchor Malo disponiendo de los bienes de Hurtado de Mendoza. En octubre, arrendó una casa situada en la calle del convento de La Concepción por 550 pesos de 8 reales durante dos años. ${ }^{58} \mathrm{Al}$ año siguiente, en enero de 1637, Margarita Malo de Molina declaró que recibió un préstamo por parte de su padre de 10000 pesos de 8 reales para redimir los censos sobre «sus posesiones» en favor del monasterio de Santa Clara. ${ }^{59}$ Ese mismo año, Margarita emitió dos poderes en favor su padre Melchor. En el primero, en marzo de 1637 , le otorga potestad para cobrar de Miońo todas las deudas y temas pendientes en virtud del testamento de Hurtado de Mendoza. ${ }^{60}$ El segundo poder, otorgado seis meses después, concedía a su padre y

${ }^{55}$ AGN, Protocolos notariales siglo XVII, N. 1210 (1622), f. 288r-289v.

${ }^{56}$ AGN, Protocolos notariales siglo XVII, N. 1210 (1622), f. 1147v-1148r.

57 AGN, Protocolos notariales siglo XVII, N. 18 (1636), f. 825-830.

${ }^{58}$ AGN, Protocolos notariales siglo XVII, N. 1237 (1636), f. 2231-2233.

${ }^{59}$ AGN, Protocolos notariales siglo XVII, N. 1239 (1637), f. 121r-121v.

${ }^{60}$ AGN, Protocolos notariales siglo XVII, N. 1239 (1637), f. 468r. 
Mateo de Pro, otro agente comercial de Malo de Molina de camino a la ciudad de Arica, en nombre de su difunto marido, cobrar todas sus deudas, hacer negocios y administrar su patrimonio, en especial una viña en dicha ciudad. ${ }^{61}$

Los beneficios obtenidos de la unión con los Hurtado de Mendoza incluyeron el acceso a la red familiar de estos últimos en la misma Península y ayuda en el pleito que Malo de Molina tenía en España con respecto a la vara de alguacil mayor de corte. En 1636, este último dio poder a Antonio Hurtado de Mendoza, comendador de cámara y secretario de cámara del rey y de la Inquisición para

que pueda representar y concertar el pleito y causa que en la real corte de Indias se sigue e trata en razón de la renunciación e propiedad del dicho oficio de alguacil mayor de corte que estoy poseyendo por renunciación que en mi hizo don Agustín de Córdoba Mesía, mi yerno difunto, y lo demás deducido en el dicho pleito la cual dicha transacción hagan en la forma e manera que según y como les pareciese y en la cantidad de pesos que ella fuere bien visto interviniendo en ella [...] para su majestad precediendo para ello lo necesario para su fin cumplido efecto y me obligan y obliguen a la paga de la cantidad de pesos que se hiciese dicha transacción para cualquier [roto] que por su majestad se pretenda declarado o por declarar en la dicha causa que se los pagare en esta ciudad en la real caja [...] y para que puedan en el dicho mi nombre pedir [roto] de poder de cualquier [roto] cualquier título e mercedes que en razón de la dicha transacción y concierto me fueren concedidos en razón de la conformidad del dicho oficio. ${ }^{62}$

Antonio de Mendoza se mantuvo como representante y ayuda de Malo de Molina en la corte del rey hasta 1637, como deja constancia en una escritura en la cual se registra que le envió 5000 pesos de 8 reales para "con ellos acudir a los negocios que tengo en corte». ${ }^{63}$ Las instancias locales parecen haber actuado a favor de este mercader dado que el propio virrey conde de Chinchón dio por cancelada la deuda, perdonándole «ocho años de frutos» y la absolución de sus bienes como

\footnotetext{
${ }^{61}$ AGN, Protocolos notariales siglo XVII, N. 17 (1637), f. 533-535v.

${ }^{62}$ AGN, Protocolos notariales siglo XVII, N. 1238 (1636), f. 1409-1410.

${ }^{63}$ AGN, Protocolos notariales siglo XVII, N. 1239, f. 864r-866v.
} 
garantía del pago, contrariando lo expedido por el Consejo de Indias. ${ }^{64}$ Así, el vínculo incluyó la contraprestación de favores entre las redes de influencia de ambos personajes.

Por último, otra alianza fundamental para comprender el proceso de integración de la familia Malo de Molina a la elite fue el matrimonio del primogénito Melchor Malo de Molina y Ponce de León con María de Aliaga y Sotomayor, descendiente del conquistador Jerónimo de Aliaga y miembro de uno de los linajes más prestigiosos de la sociedad limeña en el momento. Aliaga estuvo presente en Cajamarca durante la captura de Atahualpa, fue alférez general de Francisco Pizarro y secretario mayor de la Audiencia durante la guerra con Manco Inca. ${ }^{65}$ Este conquistador tuvo cuatro hijas, de las cuales Juana heredaría el mayorazgo de la familia tras la muerte de los demás. Esta se casó con Francisco de los Ríos, alcalde ordinario de Lima; unión de la cual nació Jerónimo de Aliaga, quien a su vez contrajo matrimonio con Francisca de los Ríos, su prima. De dicha última unión, nacería Ventura de Aliaga, quien casada con el alcalde ordinario de Lima Pedro de Aliaga y Sotomayor tuvo a María de Aliaga, heredera final del mayorazgo de dicha familia. ${ }^{66}$

Como en el caso de la unión con los Ponce de León, al momento del matrimonio, la familia Aliaga y Sotomayor parece haber estado en problemas económicos dado que para pagar la dote tuvo que comprometer el patrimonio familiar. En la escritura de dote, Ventura de Aliaga, como tenedora de los bienes de Pedro de Aliaga y Sotomayor, menciona que se tuvo que hace uso de los bienes que le correspondían al primogénito por herencia para poder dar satisfacción al monto. ${ }^{67}$ Ventura también declaró que de los 20000 pesos que por mandato del testamento de su padre le correspondían a María de Aliaga, solo era posible pagar 10000, ya que el resto había sido "consumido y gastado» y, declara ella, «no hallarme de presente con bienes bastantes para se los poder satisfacer». ${ }^{68}$

\footnotetext{
${ }^{64}$ Polanco de Santillana 1655: 22.

${ }^{65}$ Busto Duthurburu 1986, I: 56-57.

${ }^{66}$ Mendiburu 1931-1934, I: 226-227.

${ }^{67}$ AGN, Protocolos notariales siglo XVII, N. 347, f. 372r-372v.

${ }^{68}$ AGN, Protocolos notariales siglo XVII, N. 347, f. 364.
} 
Además, a cambio de la dote, la familia Malo de Molina se comprometió a dar "un cuarto de vivienda» a Ventura de Aliaga junto con 1000 pesos para alimentos y otros 3000 para otros gastos. ${ }^{69}$

En retorno, la familia Malo de Molina obtuvo una variopinta cantidad de bienes, muebles e inmuebles que sirvieron para fortalecer el patrimonio de la segunda generación. En primer lugar, 8000 pesos serían entregados en monedas y otros 10000 más «en joyas, esclavos, plata labrada, vestidos y ropa blanca conforme a la tasación hecha». En segundo lugar, se le otorgó poder a Malo de Molina para arrendar unas casas y tiendas en la ciudad de Lima. Si estas tiendas no se llegasen a arrendar, el receptor tenía derecho a cobrar 1500 pesos de 8 reales anualmente del mayorazgo de los Aliaga. ${ }^{70}$ Por último, también se le hizo entrega del «aprovechamiento de los indios del cerro de Huancavelica» ${ }^{71} \mathrm{y}$ "minas e ingenio de Castrovirreyna», que fueron cedidas a María de Aliaga por su hermano Juan de Aliaga. ${ }^{72}$

De esta manera, la familia Malo de Molina se aseguró una posición dentro de los círculos sociales más exclusivos de la sociedad limeńa y la posesión de un patrimonio más consolidado que aquel con el cual el mercader había iniciado su fortuna. Los esfuerzos de Melchor Malo de Molina y sus sucesores por establecer alianzas matrimoniales beneficiosas no concluyeron con su muerte. En su testamento, legó, por un lado, a su última hija Josefa Malo de Molina la suma de 100000 pesos de 8 reales para su futura dote y, por otro, 20000 pesos a su nieta María Clara de Mendoza, hija de Margarita Malo de Molina y Bernardino de Hurtado de Mendoza. ${ }^{73}$ Esta última lograría casarse con el capitán Nuño del Aguilar y Acuña, miembro de la guardia personal del virrey marqués de Mancera, al que le otorgó una dote de 28000 pesos de 8 reales. $^{74}$

${ }^{69}$ AGN, Protocolos notariales siglo XVII, N. 347, f. 364.

${ }^{70}$ AGN, Protocolos notariales siglo XVII, N. 347, f. 366-366v.

${ }^{71}$ AGN, Protocolos notariales siglo XVII, N. 347, f. 366r-366v.

${ }^{72}$ AGN, Protocolos notariales siglo XVII, N. 347, f. 372r-372v.

${ }^{73}$ AGN, Protocolos notariales siglo XVII, N. 1798, f. $1941 \mathrm{r}$.

${ }^{74}$ AGN, Protocolos notariales siglo XVII, N. 585, f. 1670-1670v. 
Una excepción a este comportamiento fue el matrimonio de su hija natural María Malo de Molina, de cuya madre se desconoce el nombre, con Marcos de Vergara, el principal socio comercial de Malo de Molina. ${ }^{75}$ En este caso, el matrimonio no es sino la consolidación, por medio de una vinculación social, de la existencia de una relación comercial de larga data entre ambos personajes para dar mayor seguridad a sus negocios. Pese a su condición de hija natural, Malo de Molina le aseguró para su matrimonio una dote de 9000 pesos de 8 reales con un personaje como Vergara, quién además también estaba atravesando su propio proceso de ascenso social. ${ }^{76}$ Incluso en este caso hay un esfuerzo por otorgar a sus descendientes una mejor posición social al mismo tiempo que consolidar su vínculo con un personaje central en sus operaciones comerciales.

Así, a través de las uniones matrimoniales, la familia Malo de Molina logró mantener y consolidar la posición social lograda desde su llegada al Perú. La unión, por un lado, con linajes de beneméritos en estado de necesidad económica y, por el otro, con familias pudientes ya consolidadas en la administración real le otorgó el empuje necesario para poder asentarse con mayor facilidad dentro del entramado de conexiones que conformaba la elite peruana. A cambio, las familias beneméritas ganaron un miembro capaz de manejar su patrimonio de manera efectiva y otorgarles seguridad económica. La absorción de su patrimonio, así como el uso de las conexiones de las familias para obtener beneficios, permitió que un individuo que no tenía en el Perú más de cuatro décadas lograra acceso a algunos de los círculos más exclusivos de la elite peruana. El camino hacia la integración completa no estaba del todo acabado. A la par de las uniones matrimoniales, fue necesario invertir en la adquisición de aquellos atributos que asociasen a la familia con el ideal de prestigio y estatus de la época.

75 Mogrovejo Vidal 2019: 54.

${ }^{76}$ AGN, Protocolos notariales siglo XVII, N. 1798, f. $1943 \mathrm{v}-1944$. 


\section{ANSIAS NOBILIARIAS}

Como se mencionó en la primera sección, la acumulación de dinero no equivalía necesariamente a ser aceptado dentro de los sectores más prominentes de una sociedad de antiguo régimen. Como en el caso de otros mercaderes, la posesión de dinero sin el estatus correspondiente exponía a un individuo a potenciales ataques en contextos de conflictos o pleitos. Malo de Molina estaría expuesto a este tipo de ofensas por parte de varios sectores como cuando, en 1617, un visitador se refirió a él como un «un mercader de tienda y de cortos principios». ${ }^{77}$ Además del notorio tinte despectivo de la frase y pese a que en esos momentos ya poseía cierto renombre en el comercio trasatlántico, este tipo de referencias sobre él evidencian la asociación existente entre su apellido y la actividad comercial, profesión que, para la época, todavía poseía un innegable grado de incompatibilidad con las nociones de nobleza y prestigio. De ahí que, para lograr el tan ansiado ascenso, era necesario representar y proyectar aquellos ideales nobiliarios a los cuales se buscaba ser asociado.

Un primer punto a tener en cuenta es el traslado de su persona y negocios que realizó Malo de Molina desde Huamanga hacia Lima. Como se resaltó en la sección anterior, Malo de Molina ya contaba con una posición de prestigio y era considerado como vecino en dicha ciudad. Su unión con la familia Ponce de León le garantizaba un lugar dentro de la elite huamanguina. Pese a esto, para 1610, se desplazó del interior a Lima, donde alquiló una casa cerca de la plaza Mayor. ${ }^{78}$ Además del obvio interés comercial de la mudarse a Lima, puerto central de la armada y de las rutas comerciales ultramarinas, no se puede descartar un interés de cercanía a los círculos más prestigiosos del virreinato. Como ha demostrado Fred Bronner, hay una relación muy interesante entre los matrimonios entre familias de encomenderos con migrantes espańoles llegados al virreinato del Perú a finales del siglo XVI y su posterior traslado a la capital donde era plausible hacerse de una buena posición dada

77 Lohmann Villena 1983, II: 190.

${ }^{78}$ AGN, Protocolos notariales siglo XVI, N. 226, f. 553. 
la cercanía a los diversos entornos del poder, como la corte del virrey, la Audiencia, el Cabildo, etc. ${ }^{79}$ La existencia de estos espacios cortesanos funcionaba como atracción para aquellas familias, como el caso de los Malo de Molina, que buscaban un lugar con tradiciones nobiliarias a partir del cual construir su nueva imagen.

De la misma forma que muchos en su época, Malo de Molina buscó la posesión de un cargo público que denotara arraigo y pertenencia a la ciudad al mismo tiempo que tomaba distancia del comercio como su principal profesión y actividad. El Cabildo de Lima se presentó como una institución perfecta para este cometido. Los concejos urbanos fueron espacios reservados únicamente para las elites locales, especialmente los beneméritos. En 1561, se le negó el puesto a un vecino debido a que se argumentaba que en dicha institución solo aceptaban a los que «son y an sido los más principales vecinos e conquistadores deste reyno y es oficio que en qualquier otra ciudad se husa por las personas nobles». ${ }^{80}$ Más aún en el Cabildo de Lima, donde incluso los beneméritos ejercieron un monopolio sobe los cargos concejales al punto de que se formaron grandes linajes de cabildantes encomenderos, tales como los descendientes de Francisco de Ampuero o Nicolás de Ribera. ${ }^{81}$

Desde finales del siglo XVI, este cabildo fue visto por los mercaderes de la ciudad como un espacio predilecto para dar el siguiente paso en sus trayectorias de ascenso. A través de las compras de cargo o las cesiones por parte de un familiar o personaje cercano, muchos hombres del comercio lograron el ingreso a esta institución e incluso llegaron a desplazar a las antiguas familias de encomenderos que la habían dominado desde su fundación. ${ }^{82}$ Naturalmente, la pertenencia a esta corporación otorgaba, además de cierta influencia política, la participación en las ceremonias públicas y, por tanto, el reconocimiento frente a toda la urbe de la posición social y la calidad de su apellido al pertenecer a una asociación exclusiva de los principales vecinos de la ciudad.

\footnotetext{
${ }^{79}$ Bronner 1977: 657.

${ }^{80}$ Lohmann Villena 1983, II: 198.

${ }^{81}$ Ib.: 36-38.

${ }^{82}$ Suárez 2001: 191.
} 
Malo de Molina llegó al cargo de regidor perpetuo del Cabildo de Lima el 18 de octubre de 1621 por cesión de otro de sus socios comerciales, Sebastián de Cetina. ${ }^{83}$ Con la posesión de este cargo, el otrora mercader parece haber interiorizado todos los privilegios ceremoniales que le correspondían como miembro del ayuntamiento limeño. El 19 de noviembre de 1621, Malo de Molina y Tomás de Paredes, otro regidor perpetuo, encabezaron las diligencias para hacer llegar una queja formal a los oidores de la Audiencia de Lima, debido a que consideraban que el prior y cónsules del Tribunal del Consulado habían usurpado e insultado el ordenamiento ceremonial durante las honras al rey Felipe III al posesionarse en un mejor lugar que aquel que tuvo el cabildo. Los regidores argumentaron que este tipo de comportamiento era un agravio a su condición de cabildantes y exigían que se respete el orden correcto de las ceremonias de la misma forma que sucedía en otras ciudades como México. ${ }^{84}$

Unos años después, en 1623, Malo de Molina estuvo nuevamente involucrado en un incidente relacionado a los lugares y privilegios en las ceremonias y cortejos festivos, pero esta vez con la misma corte del virrey. Durante la procesión de Santa Ana, Malo de Molina abandonó de manera abrupta el cortejo del virrey Guadalcázar debido a que, según él, se le había dado a la escolta del gobernante un lugar que los privilegiaba por encima de aquel dado al cabildo. Como consecuencia de esto, el virrey lo penalizó con una proscripción en Chilca por seis meses, 300 pesos de multa y dos años de suspensión de sus labores en el cabildo. ${ }^{85}$ Este celo por proteger su lugar en las ceremonias revela el interés de Malo de Molina por exigir que se respeten sus prerrogativas como miembro del cabildo y, por consiguiente, la posición e imagen que quería construir de cara la sociedad de la época. En este proceso de construcción, las ceremonias y honras públicas eran una oportunidad para proyectar su

${ }^{83}$ Archivo General de Indias, Sevilla [en adelante AGI], Lima, 183, N. 39, Confirmación de Oficio de Melchor Malo de Molina.

${ }^{84}$ Concejo Provincial del Lima 1935: 199-200.

${ }^{85}$ Lohmann Villena 1983, II: 190. 
nuevo estatus y la posición social que busca personificar a lado de las figuras más prestigiosas de la elite limeña.

El cargo de regidor perpetuo no sería el único con el cual se contentaría. Malo de Molina obtuvo el cargo de alguacil mayor de corte de la Audiencia de Lima por cesión de su entonces yerno Agustín Messía de Córdova en $1633 .{ }^{86}$ La obtención de la vara de alguacil estuvo acompañada de la realización de una gala en su casa principal, donde se invitó a todos los miembros de esa institución. El evento llamó tanto la atención que quedó registrado en el diario de Lima de José Antonio Suardo, quien menciona que se realizó «una comida muy espléndida» y que incluso esta fue enviada "con muy grande largueza» a aquellos personajes que no pudieron asistir al evento. ${ }^{87}$

Este tipo de cambios en la identidad asumida por Malo de Molina tiene un correlato que es posible rastrear de las categorías de arraigo usadas en los documentos notariales, especialmente la noción de vecindad. Esta categoría provino de las antiguas tradiciones castellanas para señalar la existencia de una relación contractual entre un individuo y la ciudad o pueblo donde habitaba. El vecino debía apoyar en la defensa de la ciudad en caso sea necesario. A cambio, recibía ciertos beneficios como acceso a tierra, capacidad de ser elegido para un cargo y otros privilegios. ${ }^{88}$ Esta categoría de residencia se trasladó a América durante la fundación de ciudades, pero con ligeros cambios. A diferencia de las ciudades castellanas donde era otorgado por el cabildo, en el Perú, su adjudicación dependía de un proceso informal en el que el individuo lograba ser aceptado por el resto de la comunidad como parte de ella. Es decir, dependía en buena cuenta de la habilidad para denotar reputación, calidad y honor. ${ }^{89}$

El caso de las categorías usadas por Malo de Molina para identificarse en las escrituras nos da luz sobre la forma en que era percibido por la sociedad limeña y cómo esta percepción cambió con el pasar de los años.

\footnotetext{
${ }^{86}$ Suardo 1936, I: 291.

87 Ib.: 292

${ }^{88}$ Herzog 2003: 18.

${ }^{89}$ Ib.: 61-63.
} 
En un inicio, cuando residía en Huamanga y realizaba constantes viajes a Lima por cuestiones de negocios, él aparece registrado como «morador en la ciudad de Huamanga». ${ }^{90}$ Una vez realizado su traslado e instalación en la ciudad de Lima, aparece en los documentos como «mercader» ${ }^{91} \mathrm{O}$ «residente» ${ }^{92}$. Esta era una profesión de la cual él buscaba distanciarse en términos de imagen pública por los estigmas asociados a ella y su incompatibilidad con esquemas de nobleza existentes. Ya se ha mencionado cómo en una ocasión su reputación fue atacada por dedicarse a esta actividad. De ahí su necesidad de establecerse a partir de otras categorías de identificación para continuar con su camino en el ascenso, especialmente de aquella que ya eran poseedoras del estatus al cual aspiraba llegar y no guardaban relación alguna con el comercio.

Es recién a partir de 1616 que Malo de Molina aparece en las escrituras notariales como «vecino morador» o «vecino», prueba de que tras varios años de arraigo, había conseguido la tan anhelada vecindad que lo legitimaba como un miembro de la comunidad con ciertos derechos y privilegios. Unos ańos después, junto a su designación como vecino, hicieron aparición los cargos públicos que poseía. A partir de 1621, era nombrado como "vecino y regidor del Cabildo de Lima»" y se mantendría de esta forma hasta la obtención de su segundo cargo como alguacil mayor de corte de la ciudad Lima. ${ }^{94}$ Este último parece haber sido mucho más prestigioso, ya que reemplazaría a las categorías anteriores hasta su muerte en 1639. En ningún momento intentó reafirmar su condición de mercader o construir su identidad alrededor de esa profesión. Por el contrario, su camino de ascenso fue el de adaptarse a las categorías sociales de prestigio ya existentes y que contaban con una larga tradición de denotar estatus en esta sociedad.

Esta aspiración por acercarse a la condición nobiliaria, pese a la carencia de un título, se puede observar con mayor claridad en la creación

${ }^{90}$ AGN, Protocolos notariales siglo XVI, N. 4, f. 419r-423r.

${ }^{91}$ AGN, Protocolos notariales siglo XVI, N. 226, f. 553.

92 AGN, Protocolos notariales siglo XVII, N. 1201, f. 826-831.

93 AGN, Protocolos notariales siglo XVII, N. 1209, f. 2562-2663.

${ }^{94}$ AGN, Protocolos notariales siglo XVII, N. 263, Fol. 497-503v. 
del vínculo o mayorazgo de la familia un año antes de su muerte en 1638, y bajo el cual se constituiría el patrimonio central de la familia Malo de Molina que sobrevivió hasta el siglo XVIII. El mayorazgo fue una las instituciones centrales de la nobleza castellana durante el Antiguo Régimen. Su origen data del siglo XIV y tuvo por principal objetivo evitar la desintegración del patrimonio durante el proceso de herencia y asegurar la reproducción social del estrato nobiliario. Inicialmente, su posesión estuvo restringida a la aristocracia; sin embargo, el acceso fue facilitándose progresivamente hacia otros grupos. A partir de 1505, la Corona extendió su acceso hacia los demás sectores de la sociedad que cumpliesen con una serie de requisitos bajo la figura legal del vínculo, que debía diferenciarla del mayorazgo propiamente dicho, aunque su función original se mantenía. ${ }^{95}$

De esta forma, su uso se extendió hacia otros sectores que no contaban propiamente con un título, pero sí poder económico y prestigio como patriciados municipales, elites urbanas y las nuevas oligarquías de los siglos XVI y XVII. Todas con el anhelo en común de perpetuar la posición social de prestigio de sus respectivos apellidos. Esto generó un incremento en la cantidad de vínculos existentes que llegó a su pico entre 1551 y 1650, en el que se adicionaron 1279 fundaciones, lo que representa casi el $50 \%$ de existentes para dicho periodo. ${ }^{96}$ Dentro de estas nuevas elites, se encontraban también muchas familias de mercaderes que se habían enriquecido gracias a la formación de rutas de comercio transatlánticas y la plata proveniente de América. Estos encontraron en el mayorazgo una institución conveniente para «revestir el capital, adquirido de forma más o menos respetable, de una aureola de nobleza», ${ }^{97}$ y proteger así a dichas familias contra los todavía existentes estigmas asociadas a dicha profesión.

Con el auge de las elites hispanoamericanas durante el siglo XVII, el mayorazgo encontró un espacio dentro del abanico de estrategias que poseía este sector para lograr que tanto su riqueza como la memoria del

\footnotetext{
95 Soria Mesa 2007: 228-231.

96 Ib.: 231-232

97 Vila Vilar 1991: 154.
} 
apellido se mantuviese intacta en el tiempo. ${ }^{98}$ En Nueva España, para la década de 1620 , se contabilizan alrededor de cincuenta mayorazgos pertenecientes a una amplia gama de familias de las cuales por lo menos once eran de mercaderes. ${ }^{99}$ En Quito, pese a que no tuvo un gran arraigo, el mayorazgo sí estuvo presente en algunas familias de la elite de esta ciudad. Durante el siglo XVII, se fundaron solo siete de estos vínculos, muchas de los cuales pertenecían a familias que atravesaba un proceso de ascenso social. ${ }^{100}$ Es sintomático que un proceso similar estuviese pasando en el Perú durante esta misma centuria, mucho antes de que se permita la compra de títulos nobiliarios a las elites hispanoamericanas. Según el jesuita Cobo, para 1639 en Lima existían entre catorce y quince vínculos, ${ }^{101}$ una expresión más de las ansias de algunos sectores de esta ciudad por el ascenso social.

Además de evitar la desintegración del patrimonio familiar, los mayorazgos cumplían un rol adicional en el establecimiento de un linaje y su reconocimiento público. Como ha señalado Magdalena Chocano para las familias de nobles peruanos en el siglo XVIII, la formación de un linaje se construye sobre la base una memoria familiar donde los individuos que forman parte de esta se entienden como descendientes de un antepasado común. Más allá de la existencia real o no de este antepasado, la aceptación de la familia como un miembro legítimo del estamento nobiliario por parte de los demás sectores de la sociedad dependía de la promoción pública que se haga de su apellido. La creación de un mayorazgo fue, pues, uno de los caminos preferidos por parte de estas familias para lograr su consolidación dentro la elite criolla, dado que formalizaba la existencia de una genealogía, requisito indispensable para la existencia de un linaje. ${ }^{102}$

Mucho antes que la nobleza peruana del siglo XVIII, Malo de Molina dio los primeros pasos para la creación de un linaje a partir de la creación

\footnotetext{
${ }^{98}$ Peña 1983: 219-220.

${ }^{99}$ Hoberman 1991: 232.

${ }^{100}$ Ponce Leiva 1998: 383-385.

${ }^{101}$ Cobo 1882: 78-80.

${ }^{102}$ Chocano 1995: 130-131.
} 
de su mayorazgo. En la misma línea que sus intentos anteriores por ennoblecerse, su mayorazgo resalta su necesidad de alejarse de la percepción pública de su cercanía al comercio y por enfatizar atributos poseedores de prestigio. Al igual que en las escrituras notariales, en el documento de la fundación de un mayorazgo hace gala de los dos cargos públicos en su posesión y que serán legados a su hijo, el de regidor perpetuo del Cabildo de Lima y alguacil mayor de la Audiencia de dicha ciudad. Respecto de la línea paterna, las menciones sobre los Malo de Molina en España son escuetas, pues se limitan a señalar los nombres y el lugar de origen de la familia. Por el contrario, en el lado materno sí se hace énfasis en los antepasados de Mariana Ponce de León hasta dos generaciones anteriores; además, se señala su procedencia benemérita, su participación en el proceso de conquista e incluso el cargo desempeñado por uno de ellos como gobernador de Tierra Firme. ${ }^{103}$

El mayorazgo establece ciertas condiciones que tienen como objetivo velar el mantenimiento de la memoria pública sobre la familia, evitar que esta se vincule a influencias consideradas perniciosas en la época y construir un patrimonio acorde a su nuevo estatus. Estas cláusulas funcionan como mecanismos de vigilancia permanente, que evitan, por un lado, que algún indeseable logre hacerse con el patrimonio de la familia, pero también, como mecanismo de cierre que, en el largo plazo, mantiene y reproduce las mismas costumbres y formas que constituían la base de los sectores más prestigiosos. La adherencia a estas condiciones por parte de la familia Malo de Molina pone en evidencia las expectativas sociales, y quizá también las del resto de mercaderes en la ciudad Lima, que tenían para sus descendientes.

En primer lugar, se establece claramente que, para acceder al mayorazgo creado, el candidato debe estar libre de mezclas no deseadas. Para el caso de nieto de la familia, su matrimonio debería ser aprobado antes por los fundadores del vínculo bajo pena de perderlo si no se cumplía con ello. ${ }^{104}$ Asimismo, se señala que, de no estar presentes los abuelos,

${ }^{103}$ AGN, Protocolos notariales siglo XVI, N. 347, f. 259.

${ }^{104}$ AGN, Protocolos notariales siglo XVI, N. 347, f. 271. 
el pretendiente no se debería vincular con familiar de menor estatus y que «se case con mujer noble hija de algo limpia de todos cuatro abolengos sin raza ni macula de judía ni moro ni "penitencidas" por el Santo Oficio por ningún delito descendiente de quemados y de lo contrario se hiciese luego piedad y se revoque de este dicho nuestro vinculo». ${ }^{105}$ Mantener esta "pureza» dentro del linaje no había sido motivo de controversia para el fundador de este mayorazgo, pero sí lo sería para los sus descendientes, quienes debían acoplarse a los nuevos estándares que se esperaba de ellos. La existencia de este requisito no fue justificada únicamente con el pretexto de una pérdida del prestigio de la familia, sino también respecto de la suerte del linaje, dado «que se ha visto que de la generación y descendencia que no sea limpia de haber tenido errores en ella han sucedido y suelen suceder grandes daños así para el ánima malo para el honor y la hacienda». ${ }^{106}$ Preservar la pureza del linaje era entonces también asegurar la prosperidad de la misma, así como su bienestar económico y social.

En segundo lugar, el poseedor del mayorazgo debía mantener y exteriorizar en todo momento los símbolos y el apellido de la familia. En el caso que estamos analizando, el vínculo exigía que:

Se hagan llamar pública y secretamente los apellidos de Malo de Molina y traigan sus armas y e insignias por armas principales en los escudos e blasones y sellos en el lado derecho en las escrituras que otorgaren y cartas que lo escriben y demás cosas que debieran de hacer y firmar se llamen por sobrenombre. ${ }^{107}$

Así, los creadores del mayorazgo se aseguraban de que el apellido se mantuviese por encima de aquellos que pudiesen aparecer en futuras uniones y que su despliegue permite ser reconocido de manera pública por todos los sectores de la sociedad. Esta condición fue de vital importancia para lograr este traspase desde su imagen pública como mercader hacia otra asociada a la hidalguía en un contexto donde la elite limeńa

${ }^{105}$ AGN, Protocolos notariales siglo XVI, N. 347, f. 271.

${ }^{106}$ AGN, Protocolos notariales siglo XVI, N. 347, f. 271.

${ }^{107}$ AGN, Protocolos notariales siglo XVI, N. 347, f. 271 
elaboraba su distinción del resto de la sociedad sobre la base de atributos distintos a los títulos.

Es necesario remarcar nuevamente que la familia Malo de Molina carecía de un título nobiliario, pero esto no fue impedimento para referirse a sí misma con dicho tratamiento. En el documento de fundación del mayorazgo, se remarca constantemente la importancia de que se mantenga estricta vigilancia sobre sobre las uniones matrimoniales y la conducta del primogénito de la familia "para que el dicho don Melchor Malo de Molina conserve la nobleza de sangre de hidalguía de sus progenitores queremos que el susodicho después de nuestros días o de cada uno de nos, tomare estado de matrimonio». ${ }^{108}$ De esta forma, en todo el documento, se asume por real la existencia dicha nobleza de los fundadores de este vínculo.

En tercer lugar, el vínculo cumplió el objetivo de consolidar y legar un patrimonio a los sucesores de esta familia que ofreciese los mismos indicadores de nobleza que ostentaban las familias pertenecientes a aquel estamento, especialmente en dos puntos, vivienda y tierras. En el documento, Malo de Molina lega a su primogénito su casa principal y unas tiendas ubicadas «en la calle que va de la esquina de la iglesia mayor al monasterio de la Pura y Limpia Concepción». ${ }^{109}$ Dicha propiedad fue adquirida en 1620, un ańo antes de su ingreso al cabildo, por la suma 27800 pesos y contaba con una posición privilegiada al encontrarse cerca de la plaza Mayor. ${ }^{110}$ Esta casa principal se volvió parte importante del patrimonio de la familia hasta el siglo XVIII y quedó en la memoria de la ciudad asociada a dicho apellido, al punto de que la calle donde se encontraba fue nombrada con el nombre de "Melchor Malo» hasta el siglo XIX.111

En el caso de las tierras, ni Malo de Molina ni su esposa contaban con una amplia cantidad de haciendas en Lima a partir de la cual pudiesen formar el legado a su familia. Ambos tuvieron que construirla progresivamente y dicho proceso quedó registrado en las compras enumeradas en

\footnotetext{
${ }^{108}$ AGN, Protocolos notariales siglo XVI, N. 347, f. 271.

${ }^{109}$ AGN, Protocolos notariales siglo XVI, N. 347, f. 261.

${ }^{110}$ AGN, Protocolos notariales siglo XVI, N. 347, f. 261.

${ }^{111}$ Bromley 2005: 236.
} 
la escritura del vínculo. La primera de estas se realizó en 1616, aproximadamente seis o sietes años después desde su mudanza y establecimiento en Lima. Esta propiedad rural estuvo ubicada en el valle de Late y constó de 450 fanegadas. Luego, la familia empezó a comprar unas cantidades pequeñas de tierras en los alrededores con el objetivo de unificarlas en una sola gran propiedad. En 1618, Malo de Molina compró doscientas fanegadas más de tierras para sembrar de una propiedad continua a su primera compra y en los siguientes diez años realizó cuatro compras más de setentas fanegadas en los linderos de lo ya adquirido. ${ }^{112}$ Esta propiedad es descrita en el documento de manera muy elocuente y con énfasis en su prosperidad y riqueza:

están en ellas hechas y plantadas huertas árboles frutales y cañaverales [Quemado] alfalfares y fundadas y labradas casas de vivienda corrales de ganados ranchos y dos trapiches de moler caña con cuatro calderas grandes y otras cosas y pertrechos de su [Quemado] y asimismo un molino de pan moler y una calera en todo lo cual están y tenemos cien negros y negras nuestros esclavos de [Quemado] y beneficio y [Quemado] ganado mayores y menores y cantidad e mulas caballos yeguas burros y otros pertrechos. ${ }^{113}$

Esta concentración de grandes cantidades de tierras (más de setenta fanegadas) en pocas manos fue una tendencia creciente a inicios del siglo XVII. A partir de 1580, la pequeña propiedad de tierra cultivable fue reemplazada por la existencia de grandes haciendas yuxtapuestas a unidades de procesamiento de la cosecha como molinos o ingenios. Dichas fincas estaban lejos de ser complementarias a las encomiendas y, durante este siglo, se convirtieron en parte importante de los ingresos de las familias más pudientes de la ciudad de Lima. ${ }^{114}$ En el caso de la propiedad adquirida por Malo de Molina, de la presencia de calderas, trapiches, esclavos y ganado en gran cantidad se puede intuir la necesidad de dotar a las siguientes generaciones de una unidad productiva que dotase de rentas o quizá oportunidades comerciales.

${ }^{112}$ AGN, Protocolos notariales siglo XVI, N. 347, f. 263.

${ }^{113}$ AGN, Protocolos notariales siglo XVI, N. 347, f. 263.

${ }^{114}$ Evans 1972: 72-75. 
Las afueras de la ciudad de Lima estaban rodeadas de este tipo de propiedades que proveían de abolengo a las familias propietarias. Estas podían fungir de residencias de descanso, elaboración de banquetas como fue usada por Malo de Molina después de que asumió el cargo de alguacil mayor - o incluso alojamiento para huéspedes de prestigio como algún virrey. ${ }^{115}$ En este punto es que convergen tanto la necesidad por sentar una base económica fuerte para las generaciones venideras y la exigencia de adaptarse a las convenciones sociales de la época para mimetizarse dentro del sector social más prestigioso. De ahí que en el mayorazgo se consignen condiciones a su mantenimiento que sirven para propósitos económicos y simbólicos como la exigencia, en el caso del mayorazgo que venimos analizando, de que este siempre posea un número mínimo de setenta esclavos en todo momento para su cuidado y mantenimiento. ${ }^{116}$

De tal manera, el vínculo fundado por Malo de Molina fue la consolidación de todo lo logrado en su largo recorrido por el ascenso social. En este, se dotó de todo lo necesario a las siguientes generaciones para poseer una reputación familiar nobiliaria alejada de su origen comercial. El esfuerzo no concluyó con este documento, pues, en su testamento, nuestro comerciante legó a su primogénito su cargo como regidor perpetuo del Cabildo de Lima y la vara de alguacil mayor de corte de la Audiencia. ${ }^{117}$ Malo de Molina había iniciado las diligencias para que a su hijo se le otorgue el hábito de la Orden de Santiago y con este fin dejó 400 ducados para futuros trámites. ${ }^{118}$

Malo de Molina falleció el 22 de agosto de 1639. Como era de esperarse, dejó instrucciones en su testamento para las celebraciones de su funeral y entierro. Naturalmente, estos estuvieron a acordes a su nuevo estatus, pues hicieron gala de su devoción, piedad y preocupación por los más necesitados. Dejó una cantidad de dinero para ser donada a los

\footnotetext{
${ }^{115}$ Ib.: 80-90.

${ }^{116}$ AGN, Protocolos notariales siglo XVI, N. 347, f. 270 r.

${ }^{117}$ Lohmann Villena 1983, II: 192-193.

${ }^{118}$ AHN, OM-Expedientillos, N. 2033, f. 6.
} 
niños pobres de diversos hospitales de la ciudad de Lima. ${ }^{119}$ Además, instruyó para que se fundase una capellanía de «memoria y aniversario de misas» con 600 pesos anuales, los cuales debían ser invertidos en doscientas misas por año por su alma y la de su esposa. De no contar con dicho dinero, el portador del mayorazgo estaba en la obligación de solventar esta suma a partir de las rentas de dicho vínculo. ${ }^{120}$

Las mandas del testamento respecto a su cuerpo le garantizaron un lugar de descanso privilegiado. El cuerpo debía ser depositado en el enterramiento de la iglesia de Santo Domingo, propiedad de su suegra Ventura de Aliaga, mientras se terminaban los preparativos para construir uno propio de la familia Malo de Molina. Esto último se hizo realidad el 28 de abril de 1640, cuando el cabildo eclesiástico de la catedral de Lima le otorgó a la familia uno en la capilla de Los Reyes. ${ }^{121}$ Esta capilla estaba reservada para las familias más prestigiosas de Lima y estaba adornada con las imágenes de aquellos personajes de la sociedad limeña reconocidos por su santidad como Rosa de santa María o Francisco Solano. En particular, la bóveda de los Malo de Molina se construyó como un mausoleo de mármol adornado en «cedro de barniz blanco con perfiles de oro», en el cual se talló el apellido de la familia con la inscripción «La muy noble familia Malo de Molina, de Aragón, puesta en el castillo de Cuenca, trasladada a la suprema belleza de América». ${ }^{122}$

A partir de todos estos atributos, Melchor Malo de Molina logró crear una imagen y memoria sobre su apellido tan prestigiosas como aquellas de las antiguas familias de la ciudad de Lima. Los cargos públicos, la posesión de la vecindad, el patrimonio a la usanza noble, el despliegue de los símbolos de prestigio y la posesión de un vínculo propio de su linaje sostuvieron su posición pública de estatus. Pese a la carencia de algún título, su nuevo estatus social se sostuvo sobre los mismos atributos

${ }^{119}$ AGN, Protocolos notariales siglo XVI, N. 1798, f. 1938.

${ }^{120}$ AGN, Protocolos notariales siglo XVI, N. 1798, f. 1942.

${ }^{121}$ Lohmann Villena 1983, II: 192.

${ }^{122}$ Echave y Assu 1688: 95-96. «Ex nobilisima malorun aragoniae de molina familia; postea in cuencam castellae translata novi americae decoris supremae». Gracias a Lizardo Silva por su ayuda en la traducción. 
a partir de los cuales las anteriores familias de la elite limeña habían construido la suya. Como deja en evidencia lo anterior expuesto, para los últimos años de su vida, ya todo rastro de su vinculación de Melchor Malo con el comercio había sido olvidado hasta el punto que la familia hacía uso en los documentos de las mismas categorías de nobleza para referirse a su calidad.

La segunda generación de los Malo de Molina no tuvo que atravesar por el mismo camino que el padre. Su hijo Melchor Malo de Molina y Ponce de León heredó todos los privilegios y tratamientos que su progenitor como si fuese un legado intangible. Este recibió el tratamiento de vecino desde sus primeras constancias en escrituras notariales. ${ }^{123}$ Además de los cargos ya mencionados, el hijo del antiguo mercader obtuvo uno adicional como teniente de caballería, ${ }^{124}$ y tanto él como su hijo gozaron de lugares preferenciales en los ritos y ceremonias de la ciudad. En 1659, este desfiló nuevamente, por motivo del nacimiento del príncipe heredero al trono, junto a los alcaldes de Lima "con un vestido que era asombro el mirarlo y con veinte lacayos y con unas masas que jamás se han visto en esta plaza». ${ }^{125}$ Por último, en 1663, él estuvo presente en las celebraciones por el recibimiento y desfile de la esposa del conde de Lemos como teniente y al frente de ocho compañías a caballo. ${ }^{126}$ El apellido había ganado de esta manera una lugar en las celebraciones públicas más importantes de la ciudad, principal espacio de proyección de reputación y estatus social. ${ }^{127}$

Fue recién durante la tercera generación con Melchor Malo de Molina y Aliaga que la familia logró conseguir un título de Castilla gracias a la donación de 30000 pesos a la Corona para la construcción de una fortificación en la ciudad de Portobelo. ${ }^{128}$ Esta adquisición se dio en un contexto de apertura en el acceso a dicho títulos, en el cual la Corona permitió el acceso a estos a partir de donaciones de grandes sumas de

${ }^{123}$ AGN, Protocolos notariales siglo XVII, N. 1798, f. 1938v.

${ }^{124}$ Mugaburu 1918, I: 150.

125 Ib.: 50.

${ }^{126}$ Ib.: 150.

127 Torres Arancivia 2014: 105-111.

${ }^{128}$ AGN, Real Audiencia, Causas Civiles, legajo 154, cuaderno 1299, año 1765. 
dinero que demostrasen su servicio y lealtad. Un título de esta envergadura invisibilizaba cualquiera duda o sospecha sobre el origen de la familia y se convertía en un atributo útil para la resolución de conflicto. ${ }^{129}$ Además, casi diez años después volvió a recibir otra distinción con la posesión de un hábito de la orden de Calatrava. ${ }^{130}$ No obstante, estas distinciones no se hicieron más que ratificar el estatus que gozaba la familia desde décadas atrás en la sociedad limeña.

Su procedencia del comercio desapareció por completo de la memoria pública sobre su familia. Durante las averiguaciones para el otorgamiento del hábito de la Orden de Calatrava para Melchor Malo de Molina y Aliaga, se preguntó a una serie de testigos «si sabes que el dicho pretendiente, su padre o alguno de sus abuelos hayan sido mercaderes de cualquier género de mercancía, residiendo en ella por su persona o por sus ministros o cambiador que haya tenido banco y trato de dar dineros a cambio, por si o por sus factores». ${ }^{131}$ Los más de ochenta testigos respondieron de forma negativa. La gran mayoría solo recordaba que el candidato era descendencia del conquistador Gerónimo de Aliaga, pero en ningún caso se hace alusión a la labor comercial del abuelo o ni que ese fuese el principal origen de la fortuna familiar. ${ }^{132}$

De esta forma, el imaginario creado alrededor del apellido Malo de Molina fue uno de nobleza, donde su origen comercial desaparecía por completo al punto que fue esta misma reputación la que le permitió a sus descendientes salir de algunos problemas. En noviembre de 1673, Melchor Malo de Molina y Aliaga, el nieto del patriarca mercader de la familia, encontró en su morada a su esposa en condiciones sospechosas con Agustín de Bracamonte, un criado del conde de Lemos. El descubrimiento no pasó a mayores gracias al padre de Malo de Molina, quien pudo calmar los ánimos de ambas partes. Sin embargo, este acontecimiento desencadenó un escándalo público dado que culminó en la anulación del matrimonio y posterior unión de la esposa con el dicho Agustín, y la

${ }^{129}$ Jiménez Jiménez 2017: 61-62.

${ }^{130}$ AHNE, OM-Caballeros Calatrava, Exp. 1476, f. 3.

${ }^{131}$ AHNE, OM-Caballeros Calatrava, Exp. 1476, f. 3.

${ }^{132}$ AHNE, OM-Caballeros Calatrava, Exp. 1476, f. 10r-10v. 
venta de la vara de alguacil mayor de corte por parte de Melchor Malo para poder restituir el dinero de la dote. ${ }^{133}$ Unas semanas después, Agustín de Bracamonte fue asesinado en su carroza mientras se dirigía de regreso a su vivienda y Malo de Molina apresado como principal sospechoso. El juicio concluyó en 1680 con la absolución del acusado gracias a un indulto otorgado por el virrey arzobispo Melchor Liñán y Cisneros. Así, un miembro de la familia Malo de Molina, décadas atrás denigrado por ser tan solo un "mercader de tienda y de cortos principios», era ahora objeto de conmutación por el mismo virrey arzobispo por pertenecer, según su parecer, a una «casa tan condecorada de este reino» ${ }^{134}$.

\section{Conclusiones}

Desde los primeros años de la conquista, los beneméritos o descendientes de los conquistadores constituyeron el sector más poderoso en las jerarquías sociales en Hispanoamérica. Además de las enormes rentas producidas por las encomiendas, sus apellidos eran sinónimo de estatus y eran respetados por los diversos sectores de la sociedad colonial. No obstante, la Corona les negó la posibilidad de convertirse en una aristocracia tradicional a través de la posesión de un título nobiliario y la carencia de un carácter hereditario de las encomiendas. Esto no evitó que dichas familias emulen el estilo de vida de la nobleza castellana a partir de la adopción de símbolos y honores similares. Así, la posesión, uso y proyección pública de estos atributos se convirtió la norma para denotar estatus y ser aceptado dentro de los círculos más exclusivos del virreinato. La generación de grandes mercaderes que se enriqueció con el comercio transatlántico y la extracción de plata a finales del siglo XVI e inicios del siglo XVII siguió este patrón para completar su ascenso social. Muchos de estos personajes, inicialmente migrantes advenedizos que llegaban a territorio peruano a probar suerte, emprendieron un camino hacia lo obtención de los mismos atributos con la esperanza de integrarse formalmente a los estratos sociales más altos.

${ }^{133}$ AGI, Lima 79.

${ }^{134}$ AGI, Lima 79, f. 7. 
El caso particular de Melchor Malo de Molina y su descendencia ejemplifica muy bien este proceso y visibiliza los pormenores del ascenso social en Lima durante el siglo XVII. Para ser aceptado dentro de este sector, fue necesario que dicho mercader personificase todas aquellas actitudes y posturas que proyectaban una imagen de nobleza e inicie un recorrido con múltiples aristas. Para lograrlo, Malo de Molina recurrió a dos estrategias que le permitieron empezar este camino de ascenso. Por un lado, el establecimiento de uniones matrimoniales con miembros ya establecidos de las elites como familias de encomenderos o funcionarios reales le permitió mimetizarse dentro estos sectores. Esta creación de redes familiares tuvo muchas más implicancias que la formación del vínculo en sí, pues también le permitió controlar el patrimonio de otros clanes más prestigiosos al suyo para utilizar sus bienes como las encomiendas, los cargos públicos o beneficiarse de su cercanía con el virrey o la Corona. El alto grado de integración de Malo de Molina a diversos grupos de la elite es señal de que los mercaderes aspirantes al ascenso no implicaron necesariamente la formación de un grupo separado de la elite tradicional, sino su integración a los grupos de poder ya establecidos.

Por otro lado, la necesidad de personificar una imagen de nobleza lo llevó en una búsqueda por los mismos atributos a partir de los cuales la elite había creado la suya. Estos atributos le permitieron distanciarse de su fama de mercader y del origen comercial de su fortuna, y asociar a su apellido con las mismas nociones nobiliarias de las que gozaban otras familias. La adquisición de la vecindad, la reivindicación de su identidad notarial, los cargos públicos en instituciones prestigias como el Cabildo, la obtención de casas y tierras, el establecimiento de una memoria genealógica y la formación de un mayorazgo jugaron un papel importante en rodear de un halo de nobleza la imagen pública de su familia y sus descendientes. El éxito de estas medidas se expresa en que la reputación de sus descendentes no fue vinculada al comercio, por el contrario, se le otorgó a la familia las mismas dignidades que poseía la elite mucho antes de su obtención del título nobiliario en la tercera generación.

Este caso demuestra que, para las elites americanas, la correcta adopción de signos propios del modelo tradicional de nobleza, así como la 
asimilación de su estilo de vida, todo sostenido por un caudal económico capaz de mantenerlo, eran suficiente para lograr el reconocimiento y los privilegios propios de dicho estamento. Las siguientes generaciones usaron este punto de partida para construir una memoria genealógica que asocie su apellido a percepciones de abolengo y alcurnia, de manera que quedaron grabadas en la memoria pública de la ciudad como parte de la casas y linajes más reputadas de esta tierra. Una vez logrado esto, el acceso a honores adicionales a los que la primera generación les hubiese sido imposible, como el mismo título de Castilla, fue mucho más aceptable y permitió la movilidad de un sector sin cuestionar o contradecir el ordenamiento social ya existente.

\section{BIBLIOGRAFÍA}

Andrien, Kenneth J. 2011. Crisis y decadencia: el virreinato del Perú en el siglo XVII. Lima: Banco Central de Reserva del Perú e Instituto de Estudios Peruanos.

Assadourian, Carlos Sempat. 1982. El sistema de la economía colonial: mercado interno, regiones y espacio económico. Lima: Instituto de Estudios Peruanos.

Bromley, Juan. 2005. Las viejas calles de Lima. Lima: Municipalidad Metropolitana de Lima.

Bronner, Fred. 1977. «Peruvian encomenderos in 1630: Elite circulation and consolidation». Hispanic American Historical Review. Volumen 67, número 4: 633-659. https://doi.org/10.1215/00182168-57.4.633

Busto Duthurburu, José Antonio del. 1986. Diccionario histórico biográfico de los conquistadores del Perú. Lima: Librería Studium, 2 vols.

Chocano, Magdalena. 1995. «Linaje y Mayorazgo en el Perú colonial». Revista del Archivo General de la Nación. Número 12: 129-146

Cobo, Bernabé. 1882. Historia de la fundación de Lima. Lima: Imprenta Liberal.

Concejo Provincial de Lima. 1935. Libros de Cabildo de Lima. Tomo XIX 16201624. Transcrito por Juan Bromley y Betram T. Lee. Lima: Consejo Provincial.

Cornejo, Andrés, 1779. Diccionario histórico y forense del derecho real en España. Madrid: Impresor Joaquín de Ibarra.

Echave y Assu, Francisco de. 1688. La estrella de Lima convertida en Sol sobre sus tres coronas, el Beato Toribio Alfonso Mogrovejo, su segundo arzobispo: celebrado con epitalamios sacros y solemnes cultos, por su esposa la Santa Iglesia Metropolitana de Lima, al activo y soberano influjo del Exmo. e Illmo. señor Doct. D. Melchor de Liñán y Cisneros .... descripción sacro política de las grandezas de la ciudad de Lima, y compendio histórico eclesiástico de su Santa Iglesia Metropolitana. Amberes: Juan Baptista Verdussen. 
Evans, Madeleine G. 1972. The landed aristocracy in Perú: 1600-1680. Tesis de doctarado en Filosofia. Londres: University College London.

Guibovich, Pedro. 1999. «Cultura y élites: las historias sobre lima en el siglo XVII». En Buschges, Christian y Bernal Schrater (coords.). Beneméritos, aristócratas y empresarios. Identidades y estructuras sociales de las capas altas urbanas en América hispánica. Madrid: Vervuert, 53-65. https://doi.org/10.31819/9783954879670-005

Herzog, Tamar. 2003. Defining nations: immigrants and citizens in early modern Spain and Spanish America. New Haven: Yale University Press. https://doi. org/10.12987/yale/9780300092530.001.0001

Hoberman, Louisa Schell. 1991. Mexico's Merchant Elite, 1590-1660. Silver, State and Society. Durham y London: Duke University Press.

Jiménez Jiménez, Ismael. 2017. «Las primeras almonedas de títulos nobiliarios en Perú (1681-1703)». Tempus Revista de Historia General. Número 6: 57-83. https://doi.org/10.17533/udea.tempus.n6a03

Latasa, Pilar. 2005. «Transformaciones de una élite: el nuevo modelo de "nobleza de letras" en el Perú (1590-1621)». En Navarro García, Luis (coord.). Élites urbanas en Hispanoamérica (De la Conquista a la Independencia). Sevilla: Universidad de Sevilla, 413-434.

Lockhart, James. 1982. El mundo hispanoperuano, 1532-1560. Ciudad de México: Fondo de Cultura Económica.

Lohmann Villena, Guillermo. 1983. Los regidores perpetuos del Cabildo de Lima (1535-1821): crónica y estudio de un grupo de gestión. Sevilla: Diputación Provincial de Sevilla, 2 vols.

Mendiburu, Manuel. 1931-1934. Diccionario histórico biográfico del Perú. Lima: Enrique Palacios, 11 vols.

Mogrovejo Vidal, David. 2019. Élite, comercio y movilidad social: el ascenso social de la familia Malo de Molina 1589-1640. Tesis de Licenciatura en Historia. Lima: Pontificia Universidad Católica del Perú

Mugaburu, Josephe de. 1917-1918. Diario de Lima (1640-1694). Lima: Imprenta y librería Sanmarti, 2 vols.

Peña, Federico de la. 1983. Oligarquía y propiedad en Nueva España, 1550-1624. Ciudad de México: Fondo de Cultura Económica.

Polanco de Santillana, Nicolás. 1655. El Fisco informa en el pleito con Don Melchor Malo de Molina sobre que se dé cumplimiento en todo y por todo a la Real Ejecutoria, etc. (Dar por nula la renunciación que hizo Don Agustin de Córdoba Messi de la vara de Alguacil mayor de esta Audiencia en Melchor Malo de Molina su suegro. Lima: s.i.

Ponce Leiva, Pilar. 1998. Certezas ante la incertidumbre. Élite y cabildo de Quito en el siglo XVII. Quito: Abya-Yala.

Ponce Leiva, Pilar y Arrigo Amadori. 2009. «Redes sociales y ejercicio del poder en la América Hispana: consideraciones teóricas y propuestas de análisis. Revista Complutense de Historia de América. Número 34: 15-42. 
Puente Brunke, José de la. 1991. Encomienda y encomenderos en el Perú: estudio social y político de una institución colonial. Sevilla: Diputación Provincial de Sevilla.

Rodríguez Vicente, María Encarnación. 1960. El Tribunal del Consulado de Lima en la primera mitad del siglo XVII. Madrid: Cultura Hispánica.

Sánchez Concha, Rafael. 2019. La presencia montañesa en el Perú virreinal: mentalidad y comportamiento de los cántabros en Lima entre 1700 y 1821. Tesis para optar por el grado de doctor en Historia. Huelva: Universidad de Huelva.

Soria Mesa, Enrique. 2007. La nobleza en la España moderna. Cambio y continuidad. Madrid: Marcial Pons.

Suardo, José Antonio. 1936. Diario de Lima (1629-1639). Lima: Instituto de Investigaciones Históricas de la Universidad Católica, 2 vols.

Suárez, Margarita. 2001. Desafios trasatlánticos: Mercaderes, banqueros y el estado virreinal, 1600-1700. Lima: Instituto Francés de Estudios Andinos, Fondo de Cultura Económica e Instituto Riva-Agüero. https://doi.org/10.4000/books. ifea.4039

Sullón, Gleydi. 2016. Extranjeros integrados: portugueses en la Lima virreinal, 15701680. Madrid: Consejo Superior de Investigaciones Científicas.

Torres Arancivia, Eduardo. 2014. Corte de virreyes: el entorno del poder en el Perú del siglo XVII. Lima: Instituto Riva-Agüero.

Valle Pavón, Guillermina del y Antonio Ibarra (eds.). 2017. Redes corporaciones comerciales y mercados hispanoamericanos en la economía global, siglos XVII - XIX. Ciudad de México: Instituto Mora y Facultad de Economía de la Universidad Nacional Autónoma de México.

Vila Vilar, Enriqueta. 1991. Los Corzo y los Mañara: tipos y arquetipos del mercader con Indias. Sevilla: Consejo Superior de Investigaciones Científicas.

Fecha de recepción: 4/II/2021

Fecha de aceptación: 4/III/2021 